Esta publicación cientifica en formato digital es continuidad de la revista impresa ISSN-Versión Impresa 0798-1406 / ISSN-Versión on line 2542-3185Depósito legal pp
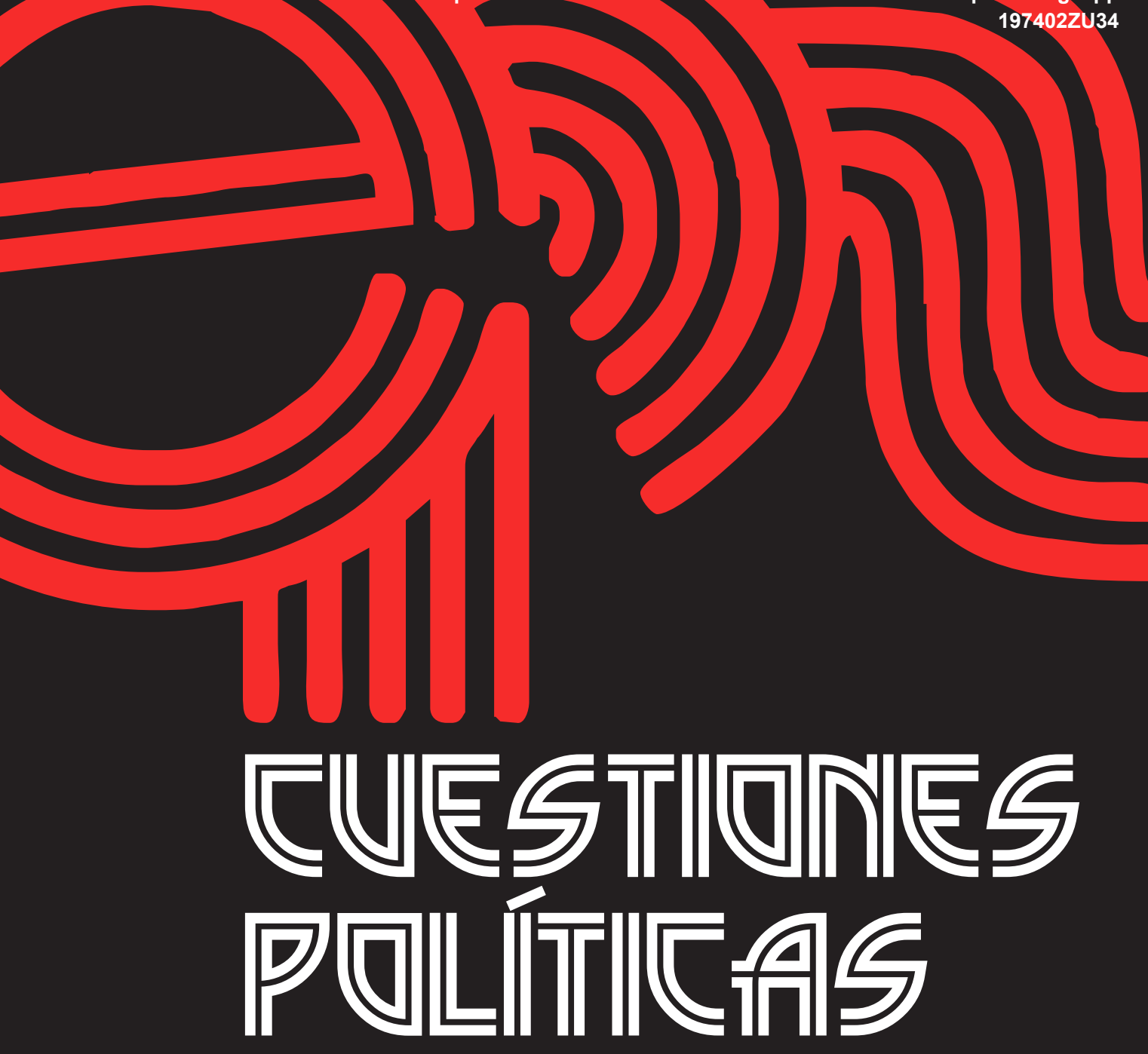

Instituto de Estudios Políticos y Derecho Público "Dr. Humberto J. La Roche" de la Facultad de Ciencias Jurídicas y Políticas de la Universidad del Zulia Maracaibo, Venezuela
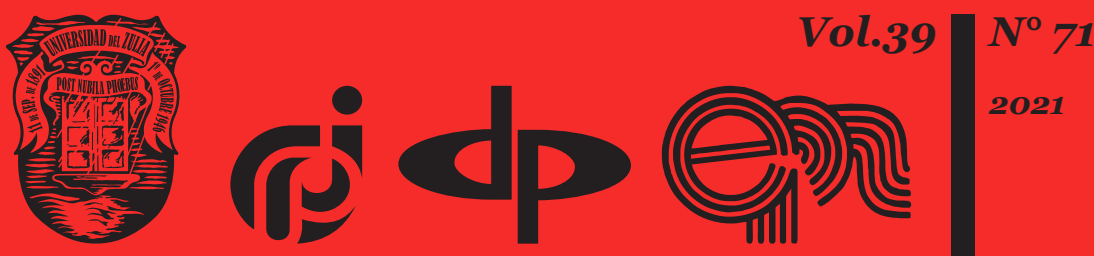


\title{
Russian court in adversarial criminal procedures
}

\section{DOI: https://doi.org/10.46398/cuestpol.3971.30}

\author{
Erna Kaysynovna Batchaeva * \\ Daria Olegovna Chistilina ** \\ Aleksandr Viktorovich Grinenko *** \\ Tatyana Kimovna Ryabinina **** \\ Vasiliy Jonovich Potapov ******
}

\begin{abstract}
This article discusses the role of the Russian court in accusatory criminal proceedings. At the legislative and practical levels, there is uncertainty about the degree of judicial activity in relation to the question of evidence. The theoretical model of the accusatory system assumes that there is minimal judicial intervention in the investigative proceedings of the parties. The latter must act and defend their position in the criminal case. The court is supposed to have a passive stance. The methodological basis of this study is composed of general scientific and legal methods such as dialectical, historical, systematic, comparative legal, formal-logical methods, etc. Most countries that practice an accusatory model of criminal justice grant the court a certain level of action that allows it to participate fully in the evidence during trials. By way of conclusion, it is suggested to improve the capabilities of the Russian court to actively investigate the evidence, as well as to offer new forms of defense to the parties.
\end{abstract}

Keywords: adversarial system; presiding judge; prosecution; defense; judicial investigation.

\footnotetext{
* Moscow State Institute of International Relations (University) of the Ministry of Foreign Affairs of the Russian Federation (MGIMO-University), Moscow, Russia. ORCID ID: https://orcid.org/oooo0002-9728-7241

** Southwest State University, Kursk, Russia. ORCID ID: https://orcid.org/oooo-ooo1-7902-3261

*** Moscow State Institute of International Relations (University) of the Ministry of Foreign Affairs of the Russian Federation (MGIMO-University), Moscow, Russia. ORCID ID: https://orcid.org/oooo-00029996-2714

***** Southwest State University, Kursk, Russia. ORCID ID: https://orcid.org/oooo-0002-0770-6802

***** Pitirim Sorokin Syktyvkar State University (SyktSU), Syktyvkar, Russia. ORCID ID: https://orcid. org/o00o-0002-3150-088X
}

Recibido el 25/09/2021 Aceptado el 13/11/2021 
Erna Kaysynovna Batchaeva, Daria Olegovna Chistilina, Aleksandr Viktorovich Grinenko, Tatyana Kimovna Ryabinina y Vasiliy Jonovich Potapov

532

Russian court in adversarial criminal procedures

\section{Tribunal ruso en procedimientos penales contradictorios}

\section{Resumen}

Este artículo analiza el papel del tribunal ruso en los procedimientos penales acusatorios. En los planos legislativo y práctico, existe incertidumbre sobre el grado de actividad judicial en relación con la cuestión de la prueba. El modelo teórico del sistema acusatorio supone que existe una mínima intervención judicial en las diligencias de investigación de las partes. Estos últimos deben tomar medidas y defender su posición en el caso penal. Se supone que el tribunal debe tener una postura pasiva. La base metodológica de este estudio está compuesta por métodos científicos y jurídicos generales como los métodos dialécticos, históricos, sistemáticos, jurídicos comparativos, formales-lógicos, etc. La mayoría de los países que practican un modelo acusatorio de justicia penal otorgan al tribunal un cierto nivel de acción que le permite participar plenamente en la prueba durante los juicios. A modo de conclusión se sugiere mejorar las capacidades del tribunal ruso para investigar activamente las pruebas, así como para ofrecer nuevas formas de defensa a las partes.

Palabras clave: sistema adversarial; juez presidente; enjuiciamiento; defensa; investigación judicial.

\section{Introduction}

In criminal procedure science, there are three main functions carried out by particular participants. These functions are criminal prosecution, defense, and resolution of the case based on its merits. Art. 15 of the Criminal Procedure Code of the Russian Federation stipulates the adversarial principle which assumes a strict division of procedural functions between the parties and the court. It is against this principle for one body to perform several functions. It can also lead to the revival of the inquisitorial process which is incompatible with the principles of a democratic State of law. Thus, the adversarial principle is a fundamental principle of the modern Russian criminal procedure which is stipulated in Art. 15 of the Criminal Procedure Code of the Russian Federation.

However simple and clear the idea may seem, it is quite complicated to implement it. Firstly, the obstacles arise from the imperfections of the legislation which does not allow the defense to unleash its potential in proving. Secondly, the parties are passive while they should take action. Finally, the court has an uncertain stance in the evidentiary activity. 


\section{Materials and methods}

The methodological base of this study is comprised of general scientific and legal methods such as dialectic, historical, systematic, comparativelegal, formal-logical methods, etc.

A systematic method helped reflect the connection between theoretical and practical approaches to the realization of the adversarial principle in criminal proceedings as well as to define the development of its nature at different time periods. The systematic approach, as the main method used by the authors, helped gain a comprehensive understanding and full analysis of debatable issues on the role of the Russian court in the adversarial criminal proceedings.

A comparative-legal method helped study the peculiarities of the legal and regulatory framework of the court's stance in criminal proceedings.

A formal-logical method helped interpret correctly the substance of legal norms which regulate adversarial trial.

All of these methods helped reveal the current problems both at the theoretical and practical levels and suggest ways to solve them.

\section{Results analysis}

In Russia, judicial proceedings are adversarial what prescribes a certain level of activity to each party and the court.

The Russian criminal procedure legislation stipulates the standards for the conduct of judicial proceedings which prescribes a strict division of functions. The court does not only settle a criminal dispute but also organizes the judicial process.

There are also specific standards of judicial proceedings established at the international level. The Universal Declaration of Human Rights, the Convention for the Protection of Human Rights and Fundamental Freedoms, the International Covenant on Civil and Political Rights enshrined the main provisions for judicial proceedings in order to ensure that the rights of the parties are protected.

According to Art. 10 of the 1948 Universal Declaration of Human Rights, "everyone is entitled in full equality to a fair and public hearing by an independent and impartial tribunal, in the determination of his rights and obligations and of any criminal charge against him”. Art. 14, Para. 1 of the 1966 International Covenant on Civil and Political Rights contains quite a similar provision. That is why the adversarial principle is followed in the majority of countries since it can ensure the equality of parties' legal possibilities as well as the impartiality and independence of the court. 
Erna Kaysynovna Batchaeva, Daria Olegovna Chistilina, Aleksandr Viktorovich Grinenko, Tatyana Kimovna Ryabinina y Vasiliy Jonovich Potapov

Meanwhile, the international legal standards do not forbid the court to take active actions. On the contrary, according to the European Court of Human Rights, it is not against the adversarial principle for the court to request the gathering of evidence. It is only necessary for the hearing to be public and for the accused to be present at it (Baranova, 2013).

Apart from its main function of solving criminal case, the court has other important roles. They are as follows: control over the preliminary investigation bodies; handling complaints on actions (or inaction) of officials responsible for criminal proceedings; managing the violations of rights, freedoms, and lawful interests of citizens, the principle of lawfulness, etc (Andreeva, Zaitsev, Emelyanov, 2017).

Moreover, the presiding judge is responsible for the strict adherence to the procedures of judicial trials. They must be respectful to all the participants, including the accused and the jurors. Inappropriate behavior towards the participants may take the form of asking incorrect questions, ignoring the parties, and accusing the innocent person. Such behavior is inappropriate and can influence the objectivity of the verdict. On the contrary, the presiding judge must prevent the participants from humiliating one another, prevent and manage conflict situations what is of utmost importance in jury trials. In addition, the presiding judge should be highly professional and avoid taking responsibilities of other participants which will allow more objectivity of the verdict (Khaldeev, 2000, p. 121122).

It should be noted that the responsibilities of the judge are exclusive since they cannot be delegated to other participants of criminal proceedings. The judge has no interest in the outcome of the case which guarantees the independence and autonomy of the court (Lutsenko, 2019).

The judiciary controls the lawfulness of actions (or inaction) and decisions of public authorities and individuals. It is possible due to the principle of the independence of the judges which allows them to solve conflicts according to their belief in the lawfulness and justification of their decision. We believe it is possible to extend the rule of the independence of judges on the court as well since it makes decisions as a unified position of a whole panel of judges. This approach does not equate the court as a body that administers justice and a judge as an individual. In its turn, it enhances the objectivity and impartiality of justice (Grinenko, 2016).

The principle of the independence of judges is stipulated in Art. 120 of the Constitution and Art. 8.1 of the Criminal Procedure Code of the Russian Federation. It implies that judges are subject only to the Constitution and federal legislation. No one can interfere in decision-making and all out-ofcourt communications with judges are prohibited by law. The judge shall not "adapt" to anyone's opinion. The judge must make a lawful, justified, and 
fair decision in order to restore law and order in society (Sharafutdinova, 2014, p. 378).

However, it is important to remember that the judge is a human being whose behavior during the trial may be influenced by a number of factors (state of mood, education, beliefs, surroundings, etc.). It is impossible to insulate the judges from external factors and pressures. The independence of judges should be ensured by a procedure for administering justice which should contain rules for criminal proceedings in order to ensure justice (Kozyavin, Chistilina, 2016). The judges should ignore external factors and aim for more objective decisions based on laws. Undoubtedly, the independence of judges and court is a crucial basis for fair decision-making and the correct functioning of the judicial system (Azarov, 2019).

Undoubtedly, great responsibility implies certain guarantees such as irremovability and inviolability of judges. It means that it is impossible to prosecute or impose sanctions on judges for their decisions in criminal proceedings if those decisions were based on law and moral beliefs.

The law stipulates that the court should settle the disputes based on their moral beliefs guided by the law and conscience. So, it is important to define these notions. A belief is a strong view on something based on a certain idea or a worldview. In criminal proceedings, it is based on the legal conscience of the court which guides the procedural decisions. In the legislation, the notion of "moral beliefs" is mentioned in terms of the evaluation of evidence when the court has to decide whether there was a crime; whether it was committed by a person in question; etc., i.e., when the court has to solve the main issues.

In the decision-making process, there are contributing factors such as relevance, clarity of circumstances of the criminal case, the presence of certain provisions in the law, the legal conscience of the judge, the exhaustiveness statement of the law, the existing enforcement practices, etc (Azarova, 2019). Meanwhile, the court is not bound by the opinions of other participants; the decisions should be based on the studied evidence. In this case, according to M.S. Strogovich (1957), the objectivity of the belief is based on facts that predetermine the objective nature of the belief. Thus, a moral belief is an intellectual process based on evidence studied during the trial and it is always motivated to some extent (Sharafutdinova, 2014).

Another prominent issue is the level of activity of the court in criminal proceedings. According to the Code of Judicial Ethics, judges should fulfill their duties with due diligence and take measures to ensure a timely and comprehensive examination of case files.

We suppose that the judge cannot be a passive arbitrator but should possess functions that will enable them to act in the evidentiary procedure with other parties. It should be noted that the Russian legislation declared 
Erna Kaysynovna Batchaeva, Daria Olegovna Chistilina, Aleksandr Viktorovich Grinenko, Tatyana Kimovna Ryabinina y Vasiliy Jonovich Potapov

the court to be the subject of evidence with investigatory functions. It is against the adversarial principle for the presiding judge to investigate the circumstances of the case since such actions aim to create conditions for the parties to perform their procedural functions and to ensure their rights as well as to determine what really happened (Yakimovich, 2015, p. 32). In addition, the presiding judge justifies his actions by the presence of evidence which is necessary to take a lawful, justified, and fair decision what is impossible if the judge sticks to a passive stance (KARJAKIN, 2016).

What is more, the court's participation in proving is aimed at ensuring the balance between public and private interests in order to ensure the legitimacy of legal and public authorities; however, the court's actions should be justified by their appropriateness for justice (Senkina, 2013). The judge should be able to take all necessary measures to eliminate doubts which impede judgement. However, we do not support the highest levels of activity of the presiding judge. We believe that such actions should seek to clarify certain facts but not to reveal new circumstances.

In this approach, it is impossible for judges to substitute one of the parties that is why their activity should focus on the main aspects which are as follows: the resolution of motions filed by the parties to obtain new evidence; enhancing the evidence-gathering activities; ensuring organizational and procedural conditions and providing procedural assistance for the parties to ensure the adversarial principle; gathering evidence only to check evidence already gathered (Plashevskaya, 2006).

The presiding judge should enhance the parties to be proactive in the investigation of evidence to ensure equality (e.g., to clarify whether the victim or the accused has questions or additional information) (Ivanov, Fadeev, Alimamedov, Dung, 2020; Ivanov et al., 2020; Pushkarev et al., 2021), to check whether the evidence is relevant, acceptable, credible, and sufficient. To complete these goals, the judge has to study all the case files in advance and devise a plan for the trial (Golovko, 2016).

It is especially relevant in the Russian criminal proceedings under the low level of activity of the defense especially during pre-trial proceedings (Kozyavin, Chebotareva, 2015). A nominal adversarial approach which is present at the pre-trial stage is substituted by a real adversarial approach during court proceedings at which the defense files a motion to investigate additional evidence over the judge who does not have any procedural interest.

It should be mentioned that the activity of the presiding judge should aim to check and evaluate the gathered evidence and not to gather new evidence. This possibility to request evidence ensures that the criminal case will be resolved, and the sentence will be justified. However, though being active, the presiding judge does not substitute one of the parties because 
he does not know what evidence (conviction or acquittal) will be gathered. Moreover, the court is allowed to act under the indictment. Thus, it proves again that the court acts only to check and evaluate the evidence which has already been gathered. In addition, only the presiding judge can make authoritative decisions that will influence the process of proving (subpoena witnesses, assign forensic expertise, etc.).

Undoubtedly, a professional judge knows legal norms and understands how to apply them. The possibility to request any evidence, which is necessary to clarify certain facts and circumstances, is granted by law. These two aspects fully condition the activity of the judge. According to L.V. Golovko (2016), these aspects can help the judge to dispense justice properly in criminal cases.

In the Soviet period, it was almost impossible to provide qualified legal assistance for everyone, so it was the only option to form an initiative court. It was the court that was in charge of studying the case files, subpoenaing witnesses, assigning forensic expertise, reviewing compliance with time limits, and addressing time extensions if necessary. According to the Statute of the People's Court of the RSFSR on October 21, 1920, the court is a body that monitors, manages, and guides the process, i.e., it was not bound by the evidence presented by the parties (Regulations on the People's Court of the RSFSR, 1920).

Art. 20 of the Criminal Procedure Code of the RSFSR stated that the court, the prosecutor, the investigator, and the interrogator must take measures as prescribed by the law to conduct a comprehensive, complete, and objective study of the case, to reveal incriminating and exculpating circumstances. However, on the approval of the new Criminal Procedure Code of the Russian Federation, this provision was no longer in force but there were several responsibilities in the process of proving that remained (Piyuk, 2017).

Undoubtedly, in order to fulfill the duty of solving the case, the judge has to be impartial, i.e., according to the European Court of Human Rights, there must not be any bias or predisposition. That is why the judge must possess a psychological competency which implies a possibility to assess one's bias, to evaluate with concern arguments of both parties, and to be able to relieve psychological tensions during the investigation of evidence (Kudryavtseva, Syskov, 2007, p. 83). Impartiality is a basis of a fair trial. If the judge acts as the principle of impartiality requires, it may increase the level of trust in the judiciary among citizens.

In verifying the impartiality, The European Court distinguishes between the subjective approach and the objective approach. The former reflects the personal beliefs of a judge regarding a particular case, the latter defines whether there was enough guarantee to eliminate doubt. It is crucial to 
Erna Kaysynovna Batchaeva, Daria Olegovna Chistilina, Aleksandr Viktorovich Grinenko, Tatyana Kimovna Ryabinina y Vasiliy Jonovich Potapov

highlight that personal impartiality shall be presumed whereas objective grounds may be not. However, the Constitutional Court of the Russian Federation demands some proof that the judge is impartial no matter how difficult it is to obtain such proof. Thus, a judge should behave in such a way so that neither the participants nor the attendees have doubts about the impartiality of the court (Trubnikova, 2013).

Therefore, the main aim of the court is the resolution of a case based on its merits and making a lawful, justified, and fair verdict which is impossible if the court does not possess an active function. The court cannot be a passive observer but shall identify all the circumstances in order to seek justice.

In addition, there certain requirements that should be met such as the representation and investigation of all pieces of evidence; the gathering is performed by legally stipulated means. A court which is passive and is not engaged in seeking the truth cannot fully protect the rights of a person, public and social interests, and, consequently, cannot uphold a fair sentence (Baranova, 2013).

Moreover, according to the decision adopted on 23 December 2008 of the plenary session of the Supreme Court of the Russian Federation "On the norms of the Criminal Procedure Code of the Russian Federation regulating appeal courts and cassation courts", a violation of the criminal procedure law affects imposing a lawful, justified, and fair sentence by deprivation or restriction of legal rights of the accused, the defendant, and other participants or by any other means. Thus, it is not always a violation of rules for the court to be active. Every case should be studied individually with consideration of all the circumstances.

It should be noted that in continental Europe, judges play a more active role in proceedings than in those countries which practice the AngloAmerican system where the activity of the judge is quite restricted.

For instance, in the USA, the Federal Rules of Evidence stipulate that the court controls the method and procedure of questioning of witnesses and presentation of evidence, the judge has a right to intervene in the presentation of evidence by the parties in order to establish true facts, and the judge can also subpoena a person as a witness (The Criminal Procedure Code of the Republic of Kazakhstan No. 231-V, 2014).

According to Art. 310, the judge has such an authority "by which he may, upon his honor and his conscience, take any measure he believes useful for the discovery of the truth" (Federal Rules of Evidence, 2014). In Germany, the court can also seek truth in spite of the presented evidence and filed motions (Bundesrecht konsolidiert: Gesamte Rechtsvorschrift für Strafproze Bordnung, 1975). 
In CIS member States, the court also plays an active role. In this way, according to the Criminal Procedure Code of the Republic of Uzbekistan, the court can conduct expertise and investigation during the trial. Moreover, according to Art. 442 of the Criminal Procedure Code of the Republic of Uzbekistan, the presiding judge begins the questioning of the accused (Criminal Procedure Code of the Republic of Uzbekistan No. 2013 - XII, 1994). According to Art. 309 of the Criminal Procedure Code of the Republic of Tajikistan, the presiding judge defines the procedure of evidence examination as agreed with the parties and authorizes the order (The Criminal Procedure Code of the Republic of Tajikistan, 2009).

\section{Conclusions}

The authors believe that the main problem is that there is still no wellfunctioning model of the adversarial criminal procedure elaborated under the Russian legislation. The court is often accused of excessive activity and substitution of one of the parties which happen when the party is not willing to act. In this case, the forced court activity can be explained by its responsibility for the legitimacy, validity, and justice of the sentence. Meanwhile, the proactive stance of the court is often viewed negatively in practice. It can lead to the annulment of the verdict despite the fact that there is no strict prohibition of court activity in criminal proceedings.

All things considered; the court is a unique public body that has a right to resolve a case based on its merits. The legislation provides a judge with a set of guarantees against negative influence from other officials and public bodies. A judge's authority shall be aimed at a fair resolution of criminal cases through establishing the facts and circumstances in order to obtain a holistic picture. The unjustified restriction of a judge's power to request evidence is a significant obstacle to a fair and objective resolution of a case.

\section{Bibliographic References $^{6}$}

ANDREEVA, Olga, I; ZAITSEV, Oleg A; EMELYANOV, Dmitry V. 2017. "On the abuse of the right to defense by the defender and how officials react to bad faith" In: Criminal Justice. No. 10, pp. 19-24.

AZAROV, Vladimir Alexandrovich. 2019. "Destructive factors of the strategy of development of criminal procedural legislation of Russia" In: Bulletin of Tomsk State University. Right. No. 33, pp. 49-59.

6 Some cited sources only have the initial of the name of the author or authors because it was impossible to locate their full name as stable the standard of this journal. 
Erna Kaysynovna Batchaeva, Daria Olegovna Chistilina, Aleksandr Viktorovich Grinenko, Tatyana Kimovna Ryabinina y Vasiliy Jonovich Potapov

AZAROVA, Ekaterina Sergeevna. 2018. "Algorithm of discretion of the court and the resolution of petitions in criminal proceedings" In: Scientific notes of the V.I. Vernadsky Crimean Federal University. Legal sciences. No. 2, pp. 101-108.

BARANOVA, Evgeniya Vladimirovna. 2013. "Modern legal positions of the Constitutional Court of the Russian Federation on the relationship between the adversarial principle and the activity of the court in criminal proceedings" In: Criminal Justice. Vol. 2, No. 2, pp. 21-23.

BUNDESRECHT KONSOLIDIERT: GESAMTE RECHTSVORSCHRIFT FÜR STRAFPROZE BORDNUNG. 1975. Available online. In: https:// www.ris.bka.gv.at/GeltendeFassung.wxe?Abfrage $=$ Bundesnormen\& Gesetzesnummer=10002326. Date of consultation: 12/11/2020.

CRIMINAL PROCEDURE CODE OF THE REPUBLIC OF UZBEKISTAN NO. 2013 - XII. September 22. 1994. Information retrieval and expert systems "All legislation of Uzbekistan". Available online. In: https://lex. uz/docs/111463. Date of consultation: 12/11/2020.

FEDERAL RULES OF EVIDENCE. DECEMBER 1. 2014. United States Courts, Washington. Available online. In: https://www.uscourts.gov/ sites/default/files/Rules\%20of\%20Evidence. Date of consultation: 16/11/2020.

GOLOVKO, Leonid Vitalievich. 2016. "The influence of the professional status of the court on the degree of its activity in criminal proceedings" In: Law. No. 1, pp. 27-38.

GRINENKO, Alexander Viktorovich. 2016. "Correlation of the concepts "court" and "judge" in the Russian criminal procedure legislation" In: Russian judge. No. 9, pp. 25-29.

IVANOV, Dmitriy Aleksandrovich; ESINA, Alla Sergeevna; FADEEV, Pavel Vladimirovich; CHASOVNIKOVA, Olga Georgievna; ZORINA, Elena Andreevna. 2020. "Crime victim compensation" In: Revista Gênero e Direito. Vol. 9, No. 4, pp. 753-759.

IVANOV, Dmitriy Aleksandrovich; FADEEV, Pavel Vladimirovich; ALIMAMEDOV, Elmir Nizamievich; DUNG, Vo Kim. 2020. "Provision of the rights and legitimate interests of legal entities that have been victims of crimes" In: Revista Turismo Estudos \& Práticas. Vol. S5, pp. $1-7$.

KARJAKIN, Evgeny Alexandrovich. 2016. "The purpose and burden of proof in relation to the formation of judicial truth in a criminal case in the court of first instance", In: Russian judge. No. 5, pp. 22-26. 
KHALDEEV, Lev Semenovich. 2000. Judge in criminal proceedings: Practical guideю Yurayt, Moscow, Russia.

KOZYAVIN, Andrey Alexandrovich, CHISTILINA, Daria Olegovna. 2016. Civil control and civil assistance in criminal proceedings of Russia: pro et contra, In: SGEM Conference Social science and Arts. Bulgarian Academy of Sciences. Albena, Bulguria, pp. 547-554.

KOZYAVIN, Andrey Alexandrovich; CHEBOTAREVA, Anna Aleksandrovna. 2015. "Evidential Powers of Defense Counsel in Criminal Proceedings of Russia in Context of Theory, Law and Practice Disconnection” In: SGEM Conference Social science and Arts. Bulgarian Academy of Sciences. Albena, Bulguria, pp. 553-560.

KUDRYAVTSEVA, A.V; SYSKOV, V.L. 2007. Evidence-based activity of the court of first instance in criminal cases. Yurlitinform, Moscow, Russia.

LUTSENKO, P.A. 2019. "Forms of the implementation of judicial power in criminal proceedings in the context of the procedural status of the court as a participant in the criminal process" In: Penitentiary Science. No. 3, pp. 376-385.

PIYUK, Alexey Valerievich. 2017. "On the question of the role of the court in proving in the modern criminal process of the Russian Federation" In: Criminal Justice. No. 9, pp. 42-45.

PLASHEVSKAYA, Anastasia Anatolyevna. 2006. Collection of evidence by courts when considering a case at first instance in the criminal process of Russia. Publishing house of scientific and technical literature. Tomsk, Russia.

PUSHKAREV, Viktor Victorovich; GAEVOY, Alexander Ivanovich; KOLCHURIN, Andrei Gennadievich; BUKHAROV, Nikolay Nikolaevich; PCHOLOVSKY, Nikolay Kazimirovich. 2021. "Ensuring the principle of adversarial parties by the investigator at the end of the criminal prosecution" In: Laplage em Revista (International). Vol.7, No. Extra A, pp. 304-310.

REGULATIONS ON THE PEOPLE'S COURT OF THE RSFSR. October 21. 1920. Available online. In: https://pravo.ru/store/doc/doc/ESU18782 o_20140421_141452_53397.pdf. Date of consultation: 16/11/2020.

SENKINA, Zhanna Sergeevna. 2013. "On the content of the concept of "Court activity" at various stages of the development of criminal proceedings" In: Legal science and practice: Bulletin of the Nizhny Novgorod Academy of the Ministry of Internal Affairs of Russia. No. 23, pp. 209-212. 
Erna Kaysynovna Batchaeva, Daria Olegovna Chistilina, Aleksandr Viktorovich Grinenko, Tatyana Kimovna Ryabinina y Vasiliy Jonovich Potapov

SHARAFUTDINOVA, Zarina Igorevna. 2014. "On the formation of an internal conviction of a judge in an adversarial criminal procedure" In: Fundamentals of Economics, Management and Law. Vol. 2, No. 14, pp. 93-95.

STROGOVICH, Mikhail Solomonovich. 1957. "On inquiry and preliminary investigation and on a single investigative apparatus" In: Socialist legality. No. 5, pp. 54-78.

THE CRIMINAL PROCEDURE CODE OF THE REPUBLIC OF KAZAKHSTAN NO. 231-V. JULY 4. 2014. Information and legal system of normative legal acts of the Republic of Kazakhstan. Available online. In: http:// adilet.zan.kz/rus/docs/K1400000231. Date of consultation:16/11/2020.

THE CRIMINAL PROCEDURE CODE OF THE REPUBLIC OF TAJIKISTAN. DECEMBER 3. 2009. National Center for Legislation under the President of the Republic of Tajikistan: official website. Available online. In: http:// ncz.tj/content/\%20the\%20criminal-\%2oprocedural-code\%20of\%20 the\%2orepublic-tajikistan. Date of consultation: 28/09/2020.

TRUBNIKOVA, Tatiana Vladimirovna. 2013. “The beginning of the impartiality of the court in the criminal process of the Russian Federation: undeserved neglect" In: Criminal Justice. Vol. 1, No. 1, pp. 51-55.

YAKIMOVICH, Yuri Konstantinovich. 2015. Participants in the criminal process. Legal Center. Saint Petersburg, Russia. 
Vol. 39 N $^{\circ} 71$

Esta revista fue editada en formato digital y publicada en diciembre de 2021, por el Fondo Editorial Serbiluz, Universidad del Zulia. Maracaibo-Venezuela 